\title{
Exploring forest and recreation management preferences of forest recreationists in Alberta
}

\author{
by Bonita L. McFarlane ${ }^{1}$ and Peter C. Boxall ${ }^{1}$
}

Understanding social values of stakeholder groups is an essential part of ecosystem management. Values of one stakeholder group, campers at managed sites in the Rocky-Clearwater Forest of Alberta, were examined using campground management preference and forest attitude scales. On-site and mail surveys were used to collect data from campers during 1994. Four specialization clusters were delineated that identified differences in management preferences. Campers most familiar with the area and those with the most camping experience were the least supportive of traditional timber management and campground development. Overall, campers did not support increased facility development at campgrounds. This study suggests that campers may be supportive of an ecosystem approach to forest management that incorporates nontimber values.

Key words: camping, ecosystem management, forest recreation, management preferences, recreation specialization, social values
La compréhension des valeurs sociales des groupes d'intervenants constitue un élément essentiel de l'aménagement de l'écosystème. Les valeurs d'un groupe d'intervenants, les campeurs des sites aménagés de la forêt Rocky Clearwater en Alberta, ont été étudiées au moyen des échelles de préférence reliée à l'aménagement du site et à l'attitude face à la forêt. Des sondages sur place et par la poste ont été utilisés pour recueillir des données sur les campeurs au cours de 1994. Quatre regroupements spécialisés ont été délimités et soulignaient les différences au niveau des préférences d'aménagement. Les campeurs les plus familiers avec le site ainsi que ceux qui avaient le plus d'expérience de camping étaient les personnes les moins portées à appuyer l'aménagement forestier et le développement des sites de camping traditionnels. De façon générale, les campeurs n'appuyaient pas le développement accru des facilités sur les terrains de camping. Cette étude laisse entendre que les campeurs peuvent appuyer une approche écosystémique d'aménagement forestier qui comprend des valeurs non reliées à la matière ligneuse.

Mots clés: camping, aménagement écosystémique, activités récréatives forestières, préférences d'aménagement, spécialisation récréative, valeurs sociales

\section{Introduction}

Traditionally forest management on public lands has focused primarily on timber production and economic development. However, a new paradigm for management is emerging that includes emphasis on sustainable development, public involvement in decision making, harmony with nature, and decreased emphasis on science and technology (Bengston 1994). In response to this new paradigm, agencies managing forested public lands are moving toward ecosystem management. Ecosystem management in Canada, however, has emphasized an ecological approach where forests are managed largely based on biological principles (Kimmins 1995). Other components of ecosystem management, i.e. social and economic principles, have not received as much attention. In order to make forestry practices responsive to social values, it is essential to increase our understanding of these values (Bengston 1994). In practice, this amounts to a more holistic approach to ecosystem management.

Understanding forest values of various stakeholder groups is fundamental to a social component of ecosystem management and can benefit ecosystem management by determining how people will react to forest practices, establishing appropriate management goals, assisting public involvement processes, and facilitating conflict management and resolu-

${ }^{1}$ Northern Forestry Centre, Canadian Forest Service, 5320122 Street, Edmonton, Alberta, Canada T6H 3S5. tion between groups of forest stakeholders (Bengston 1994). One means to increase understanding of forest values is by examining attitudes of stakeholder groups toward the social, managerial and biophysical aspects of forests. However, attitude research in forest management has lacked standardized measurement instruments. The development of standardized attitude scales is necessary for long term analysis of attitude change, comparisons between stakeholder groups, and analysis of geographical variation in attitudes.

Identifying and understanding recreationists' views is an important consideration in a socially based approach to ecosystem management because recreationists are direct users of forested lands and participation in forest recreation has been associated with attitudes toward the environment (Van Liere and Noe 1981; Jackson 1986) and natural resource management (Jackson 1987). For example, people who prefer appreciative outdoor recreational activities (e.g. hiking) hold stronger pro-environmental attitudes and are more supportive of resource preservation than those who prefer mechanized (e.g. snowmobiling) or consumptive activities (e.g. hunting) (Jackson 1986, 1987). Jackson (1987) also concluded that participants in different types of recreational activities may have divergent views about resource preservation and development and therefore, policy decisions may not satisfy all recreationists equally.

In addition to differences among participants in different activities, there may be subtypes of participants within an activity which also have differing views on natural resource man- 
agement. One aspect of recreation that may influence attitudes toward natural resources and may be used to distinguish subtypes is the amount of experience an individual has with an activity. The concept of recreation specialization is one means for examining experience. Specialization theory suggests that participants in an activity can be segmented based on the amount of experience they have and their psychological attachment to the activity (Bryan 1977). One aspect of this theory relevant to natural resource management is the shift in attitudes as participants become more concerned with conservation aspects of the resource. Specialized individuals have been shown to exhibit a greater concern for conservation by preferring less management intervention and manipulation of the resource than their less specialized counterparts. For example, Bryan (1977) found that as specialization increased among anglers, attitudes shifted from an orientation of catching fish to concern for the conservation of fish. Kellert (1985) found that experienced birdwatchers scored higher on naturalistic and ecologistic dimensions of attitudes toward wildlife and concluded that active participation may promote an understanding, awareness and concern for the natural environment. Virden and Schreyer (1988) found backpacking specialization positively correlated with preferences for natural settings and negatively correlated with the presence of natural resource extraction industries. Williams (1988) suggested that specialists may be more sensitive to changes in the management of an area and may be more opinionated about management activities and McIntyre and Pigram (1992) suggested that specialized vehicle-based campers were the most critical of management actions. These findings may be relevant to forest management because participants within an activity may not represent a homogeneous group of stakeholders and may hold differing attitudes toward resource management.

These ideas are explored further in a study of campers in the Rocky-Clearwater Forest of Alberta. This paper presents the preliminary development of a forest management attitudes scale. This is then linked to an investigation of campground management preferences and development of a subtypology of campers based on recreation specialization. The development of a subtypology allows a detailed examination of attitude differences among campers.

\section{Methods}

The Rocky-Clearwater Forest consists of about 1.8 million ha of primarily publicly owned land situated in the foothills of the Rocky Mountains (Fig. 1). It is located within a two to three hour drive from the two major urban centres of the province, Edmonton and Calgary. This area was chosen because it has a long history of forest management and the existence of historical recreational use data. This forest was also chosen because it has two forest management agreements (FMA) with forest based industries. Forestry activity is expected to increase in the future with the recently agreed upon expansion of one FMA. With this expansion, the potential for conflict between forest industry development and recreation may increase.

Forest recreation area (FRA) campgrounds evolved from informally established camps on public land. Although such camping is legal, concern with fire hazard and environmental impacts led the Alberta Forest Service to establish formalized campgrounds at popular informal camping sites. Currently FRAs

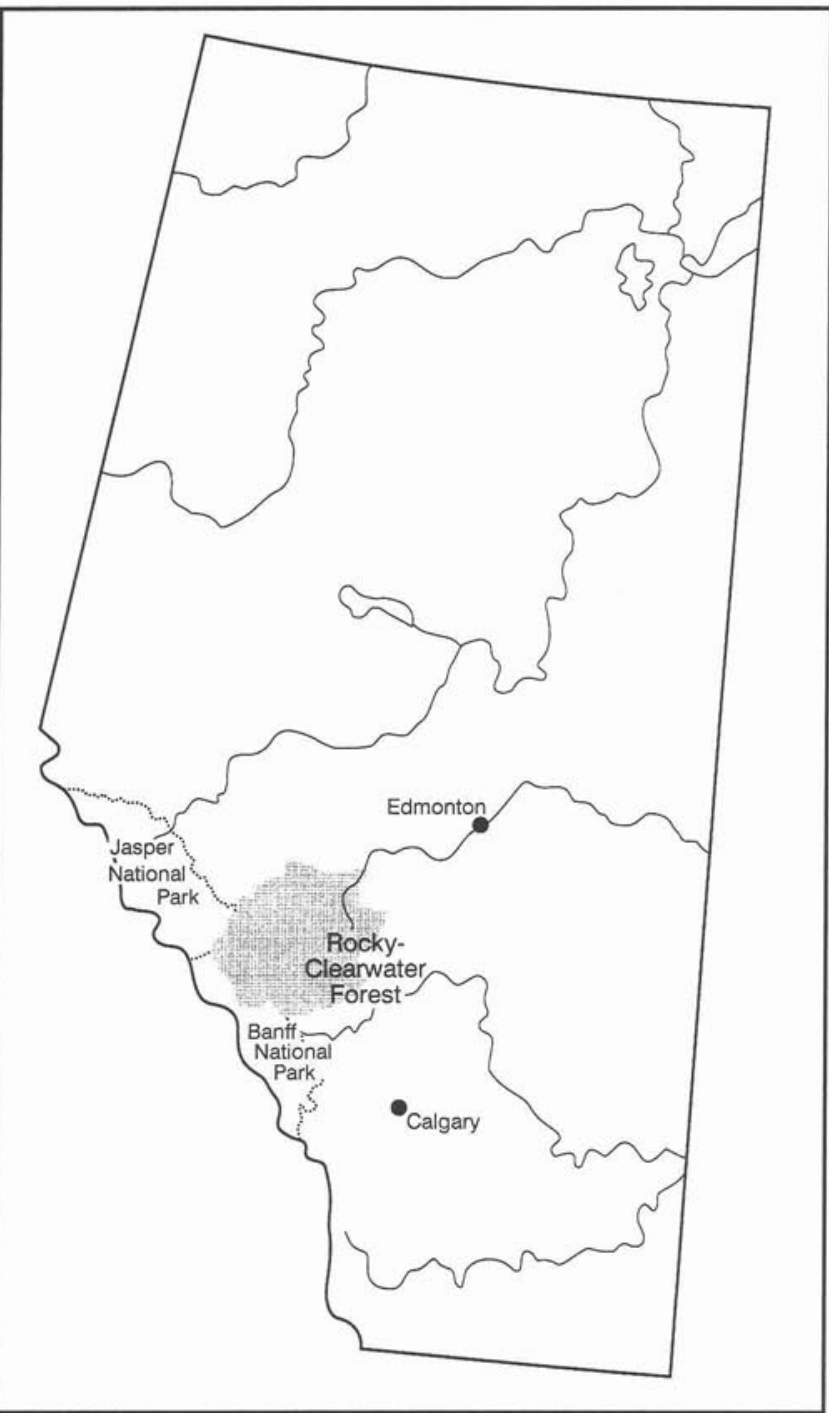

Fig. 1. Location of the Rocky-Clearwater Forest in Alberta.

provide a semi-primitive, vehicle-based camping opportunity and are classified as providing rustic or basic services. Most campgrounds have drive-in sites with a picnic table, fire ring, garbage containers, firewood, vault or pit toilets, gravel tent pads, and water pumps. Rustic campgrounds differ from basic campgrounds in that they have fewer patrols and less maintenance and servicing and may not have a gravel tent pad or water supply. A camping fee was first initiated in 1992 and in 1994 was increased to $\$ 9.00$ at basic campgrounds and $\$ 7.00$ at rustic campgrounds. In general, FRAs differ from other publicly owned campgrounds in that they are less developed, provide fewer services and facilities and charge a lower camping fee. However, more facilities and services, privatization, and tourism developments have been proposed for some FRAs. These plans represent another potential conflict between development and recreation use. This conflict could occur between participants in different recreational activities, between subgroups of participants in the same activity, or between individuals with industrial and recreational interests.

Personal interviews were conducted with campers at 10 of the 33 FRAs that collect camping fees and receive the most 


\begin{tabular}{|c|c|c|c|}
\hline \multirow[b]{2}{*}{ Items } & \multicolumn{3}{|c|}{ Factor loadings $^{1}$} \\
\hline & $\begin{array}{c}\text { Factor } 1 \\
\text { Self-expression }\end{array}$ & $\begin{array}{c}\text { Factor } 2 \\
\text { Attraction } \\
\end{array}$ & $\begin{array}{c}\text { Factor } 3 \\
\text { Centrality }\end{array}$ \\
\hline When I am camping I can really be myself & .76 & - & - \\
\hline Camping offers me relaxation when life's problems build up & .76 & - & - \\
\hline Camping says a lot about who I am & .69 & - & - \\
\hline Camping is very important to me & .65 & - & - \\
\hline I have little or no interest in camping ${ }^{2}$ & - & .85 & - \\
\hline I do not particularly like camping ${ }^{2}$ & - & .84 & - \\
\hline Camping is one of the most enjoyable things I do & - & .63 & - \\
\hline Camping is one of the most satisfying things I do & - & .59 & - \\
\hline Camping is nothing more than a place to stay while I do other things ${ }^{2}$ & - & .35 & - \\
\hline Most of my friends are in some way connected to camping & - & - & .83 \\
\hline I enjoy discussing camping with my friends & - & - & .77 \\
\hline I find a lot of my life is organized around camping & - & - & 62 \\
\hline You can tell a lot about a person when you see them camping & - & - & .49 \\
\hline Eigenvalues $^{3}$ & 5.26 & 1.71 & 1.03 \\
\hline Percentage of variance & 40.5 & 13.2 & 8.0 \\
\hline Cumulative percentage & 40.5 & 53.7 & 61.7 \\
\hline Cronbach's alpha & .81 & .74 & .75 \\
\hline
\end{tabular}

${ }^{1} \mathrm{~A}$ minimum loading of 0.35 was used to identify items belonging to a component.

${ }^{2}$ Items were reverse coded for analysis.

${ }^{3}$ Components were extracted until the eigenvalue was $\leq 1.0$.

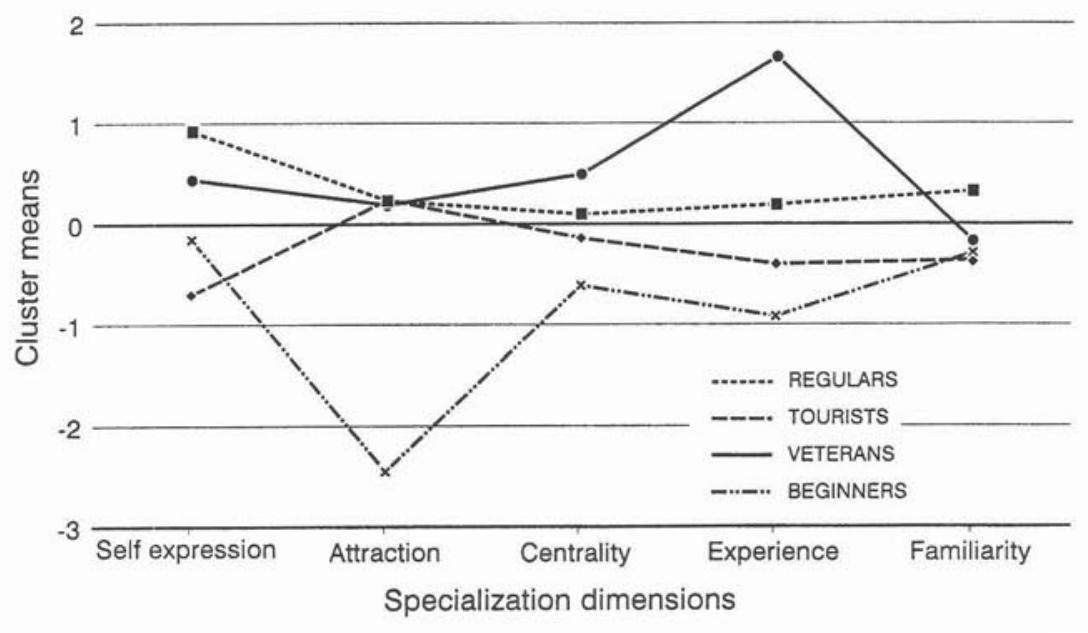

Fig. 2. Recreation specialization cluster profile.

use: Brazeau Reservoir, Medicine Lake, Prairie Creek, Chambers Creek, Fish Lake, Goldeye Lake, Crescent Falls, Ram Falls, Two O'Clock Creek, and Thompson Creek. The survey collected information on use patterns and trip characteristics, and solicited names and addresses for a follow-up mail survey. Interviews were conducted on weekends and weekdays primarily during morning and evening hours from the Victoria Day weekend in May through the Labour Day weekend in September 1994. On any given sampling day, all available camping parties in a sampled campground were asked to participate in the survey. Twelve camping parties refused to participate. A total of 1,006 Alberta residents were interviewed. Of these, 964 agreed to participate in the mail survey.

The mail survey collected information on attitudes toward forest management, preferences for facilities and services at FRAs, camping experience, and socioeconomic data. The initial mailing occurred in January 1995. About one week after the initial mailing, a reminder postcard was sent and about one month after the initial mailing another questionnaire was sent to those who had not yet responded. A total of 805 questionnaires were returned, which after adjusting for undeliverables represented an $87 \%$ response rate. For analyses, data from the on-site and mail surveys were combined resulting in a total of 740 identifiable respondents who completed both surveys.

Specialization was measured following the procedures established by McIntyre and Pigram (1992). Specialization is usually measured by variables representing behavioral and psychological dimensions. The behavioral dimension was assessed by past camping experience and familiarity with the FRA. A composite index comprised of the number of years of camping experience and of the number of camping trips per year was used as a measure of past experience. Familiarity with the FRA was based on the number of previous visits in the last 10 years. The psychological dimension of specialization was measured using the 13 "enduring involvement" items proposed by McIntyre and Pigram (1992) (Table 1). Enduring involve- 


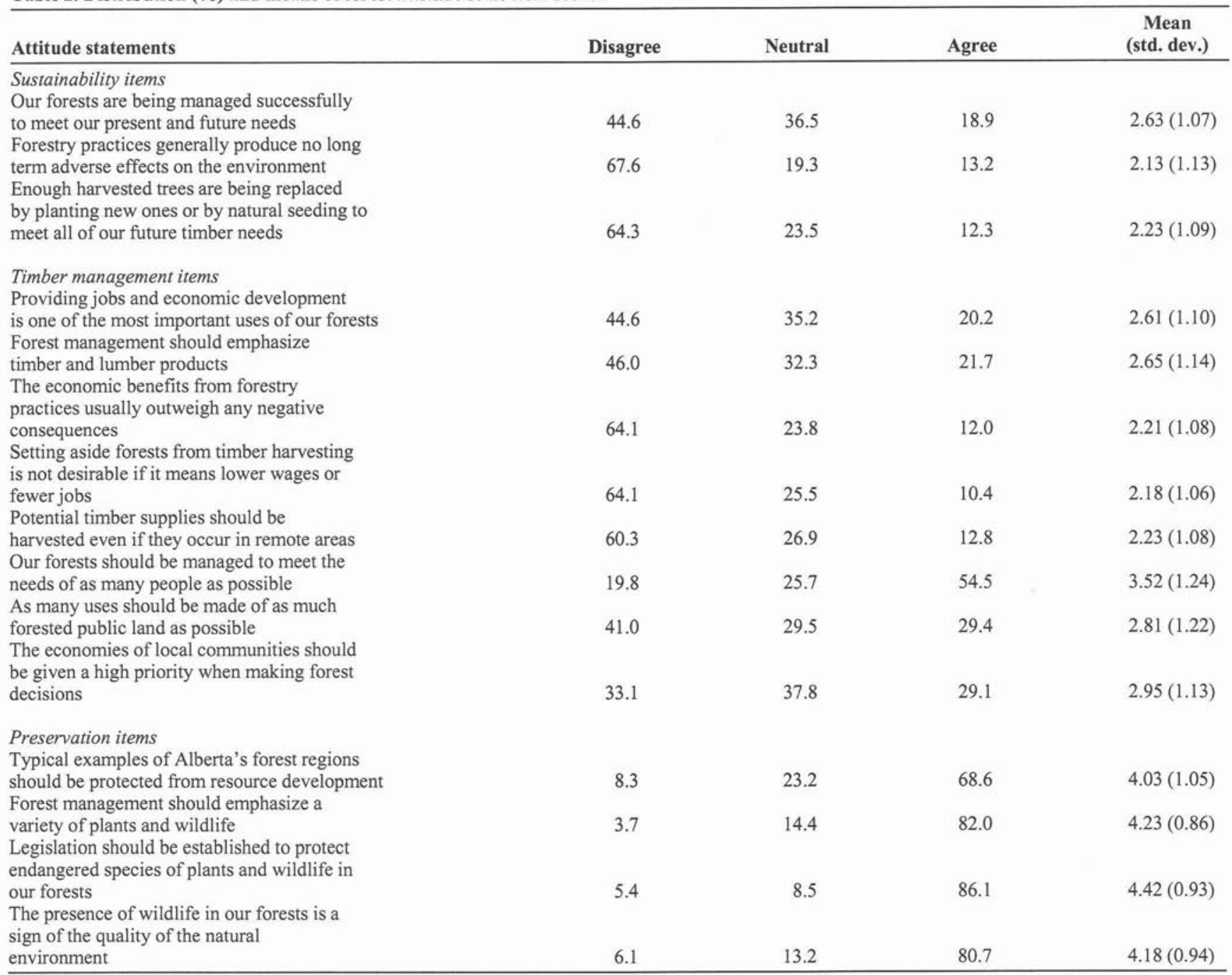

${ }^{1}$ Measured on a scale of 1 to 5 , where $1=$ strongly disagree and $5=$ strongly agree.

ment is a measure of the affective attachment or commitment of individuals to the activity and is comprised of three components: Attraction, Centrality, and Self-expression. Respondents rated the enduring involvement items on a scale of one to five ranging from "strongly disagree" to "strongly agree."

The 13 enduring involvement items were factor analyzed using principal component analysis with varimax rotation to identify the three components. Reliability of the components was examined using Cronbach's alpha. A regression component score was calculated for each of the components for each individual. The component scores, and prior experience and familiarity measures were standardized to a mean $=0$ and standard deviation $=1$. To identify subtypes of campers a discrete cluster analysis was performed on the standardized specialization variables (FASTCLUS procedure, SAS Institute Inc. [1989]).

A scale to measure attitudes toward forest management was developed based on a review of the literature and management issues of concern in Alberta. Items were selected to measure individuals' beliefs on preservation, timber management, economic development, and sustainable aspects of forest management. Several items were included from previous studies (Dunlap and Van Liere 1984; Jackson 1986; Jackson 1987; Steel et al. 1994) and were reworded to suit the Alberta forest management context. Respondents rated a series of 15 statements on a five-point Likert scale ranging from "strongly disagree" to "strongly agree."

Preferences for facilities and services at FRA campgrounds were measured by rating 15 items on a five-point Likert scale ranging from "not at all desirable" to "very desirable." Items ranged from facilities requiring extensive development and large capital investment (e.g., commercial lodges) to services requiring minimal development and investment (e.g., maps of recreational opportunities).

\section{Results}

The factor analysis identified three components of enduring involvement corresponding to McIntyre and Pigram's (1992) Attraction, Centrality, and Self-expression components (Table 1). Factor one represented the Self-expression component. It refers to how a person perceives camping as a reflection of their personality and consists of items relating to escape and 
Table 3. Mean scores ${ }^{1}$ of forest attitude scale items by camping specialization clusters

\begin{tabular}{|c|c|c|c|c|c|c|}
\hline \multirow[b]{2}{*}{ Management item } & \multicolumn{4}{|c|}{ Specialization cluster } & \multicolumn{2}{|c|}{ ANOVA } \\
\hline & Regulars & Beginners & Veterans & Tourists & $F$ value & $p$ \\
\hline \multicolumn{7}{|l|}{ Sustainability items } \\
\hline $\begin{array}{l}\text { Our forests are being managed successfully to meet our present and } \\
\text { future needs }\end{array}$ & 2.67 & 2.84 & 2.52 & 2.60 & 1.22 & .2999 \\
\hline $\begin{array}{l}\text { Forestry practices generally produce no long term adverse effects on the } \\
\text { environment }\end{array}$ & 2.14 & 2.67 & 1.90 & 2.10 & 5.52 & .0009 \\
\hline $\begin{array}{l}\text { Enough harvested trees are being replaced by planting new ones or by } \\
\text { natural seeding to meet all of our future timber needs }\end{array}$ & 2.30 & 2.64 & 2.00 & 2.18 & 4.72 & .0029 \\
\hline \multicolumn{7}{|l|}{ Timber management items } \\
\hline $\begin{array}{l}\text { Providing jobs and economic development is one of the most important } \\
\text { uses of our forests }\end{array}$ & 2.59 & 2.89 & 2.62 & 2.60 & 1.17 & .3192 \\
\hline Forest management should emphasize timber and lumber products & 2.68 & 2.74 & 2.68 & 2.59 & 0.42 & .7368 \\
\hline $\begin{array}{l}\text { The economic benefits from forestry practices usually outweigh any } \\
\text { negative consequences }\end{array}$ & 2.23 & 2.59 & 2.10 & 2.13 & 3.02 & .0293 \\
\hline $\begin{array}{l}\text { Setting aside forests from timber harvesting is not desirable if it means } \\
\text { lower wages or fewer jobs }\end{array}$ & & 242 & 221 & 211 & 1.44 & 2309 \\
\hline $\begin{array}{l}\text { Potential timber supplies should be harvested even if they occur in } \\
\text { remote areas }\end{array}$ & 2.19 & 2.56 & 2.10 & 2.23 & 2.24 & .0819 \\
\hline $\begin{array}{l}\text { Our forests should be managed to meet the needs of as many people } \\
\text { as possible }\end{array}$ & 3.68 & 3.37 & 3.61 & 3.46 & 2.00 & .1123 \\
\hline As many uses should be made of as much forested public land as possible & 2.86 & 3.19 & 2.70 & 2.78 & 2.21 & .0855 \\
\hline $\begin{array}{l}\text { The economies of local communities should be given a high priority } \\
\text { when making forest management decisions }\end{array}$ & 3.01 & 3.23 & 3.00 & 2.83 & 2.53 & .0558 \\
\hline \multicolumn{7}{|l|}{ Reservation items } \\
\hline $\begin{array}{l}\text { Typical examples of Alberta's forest regions should be protected } \\
\text { from resource development }\end{array}$ & 4.16 & 3.59 & 4.13 & 3.99 & 5.05 & .0018 \\
\hline Forest management should emphasize a variety of plants and wildlife & 4.43 & 3.70 & 4.44 & 4.13 & 15.96 & .0001 \\
\hline $\begin{array}{l}\text { Legislation should be established to protect endangered species of plants } \\
\text { and wildlife in our forests }\end{array}$ & 4.56 & 3.83 & 4.55 & 4.38 & 10.68 & .0001 \\
\hline $\begin{array}{l}\text { The presence of wildlife in our forests is a sign of the quality of the natural } \\
\text { environment }\end{array}$ & 4.38 & 3.96 & 4.31 & 4.09 & 6.34 & .0003 \\
\hline
\end{tabular}

${ }^{1}$ Rated on a scale of 1 to 5 , where $1=$ strongly disagree and $5=$ strongly agree.

freedom. Factor two represented the Attraction component and consists of items relating to the enjoyment and importance of camping to the individual. Factor three represented the Centrality component and refers to the role camping plays in an individual's life and has a strong social content. All items except "Camping is very important to me" and "You can tell a lot about a person when you see them camping" loaded on the same components described by McIntyre and Pigram (1992). In their study these items loaded on the Attraction and Self-expression components, respectively.

The cluster analysis produced four discrete clusters (Fig. 2). For ease of presentation the clusters were named Beginners, Veterans, Regulars, and Tourists. Beginners comprised $7 \%$ of the sample. Respondents in this group had the least camping experience and scored lowest on the Attraction and Centrality components of enduring involvement suggesting that they did not rate the enjoyable nor social aspects of camping as high as the other group. Veterans comprised $15 \%$ of the sample and had the highest experience score. Individuals in this group also had the highest Centrality score suggesting camping represents a medium for social interaction for these respondents. Regulars comprised $32 \%$ of the sample and were the most familiar with the FRAs. Members of this group had the highest Self-expression score suggesting that camping represents predominantly a means of escape and freedom for these individuals. Tourists comprised $45 \%$ of the sample. While members of this group have more camping experience than Beginners they were the least familiar with the FRAs suggesting they may be passing through or touring the area for the first time. This group scored lower on Self-expression, but higher on Attraction than the other groups, suggesting camping is not as important as a means of escape for these individuals but is more important as an enjoyable experience.

The distribution of the forest attitude item scores (Table 2) shows that a minority of respondents agreed with the statements that forests are being managed successfully to meet present and future needs (19\%), forestry produces no long-term adverse effects (13\%), and enough harvested trees are being replaced to meet future needs $(12 \%)$. This suggests that a minority of campers agree that current forest management is accounting for our future timber needs. A minority of respondents also agreed on economic development and traditional timber management items such as providing jobs $(20 \%)$, emphasizing timber and lumber products (22\%), and economic benefits outweighing negative consequences $(12 \%)$. The majority of campers $(55 \%)$ agreed that forests should be managed to meet as many people's needs as possible. The majority also agreed with items relating to preservation aspects of management such as setting aside typical examples of forest regions (69\%), emphasizing a variety of plants and animals $(82 \%)$, protecting endangered species through legislation $(86 \%)$, and wildlife being a sign of the quality of the environment $(81 \%)$. 


\begin{tabular}{|c|c|c|c|c|c|c|}
\hline \multirow[b]{2}{*}{ Management item } & \multicolumn{4}{|c|}{ Specialization cluster } & \multirow{2}{*}{$\begin{array}{r}\text { ANOVA } \\
F \text { value }\end{array}$} & \multirow{2}{*}{$\begin{array}{r}\text { Total } \\
\text { sample }\end{array}$} \\
\hline & Regulars & Beginners & Veterans & Tourists & & \\
\hline Showers & 2.74 & 3.09 & 2.69 & 3.01 & $3.30 * *$ & 2.88 \\
\hline Flush toilets & 2.46 & 2.70 & 2.36 & 2.64 & 1.99 & 2.55 \\
\hline Row-boat or canoe rentals & 2.12 & 2.62 & 2.12 & 2.26 & $2.95 * *$ & 2.33 \\
\hline Bike rentals & 1.96 & 2.11 & 1.97 & 2.06 & 0.60 & 2.01 \\
\hline Horse rentals & 2.09 & 2.38 & 2.10 & 2.29 & 1.99 & 2.20 \\
\hline Stores selling supplies & 2.27 & 2.64 & 2.26 & 2.40 & 1.72 & 2.34 \\
\hline Fast food outlet & 1.21 & 1.41 & 1.37 & 1.29 & $2.26 * * *$ & 1.29 \\
\hline Bundles of firewood for sale & 2.34 & 2.81 & 2.49 & 2.55 & 1.90 & 2.50 \\
\hline Paved road to the campground & 2.62 & 2.65 & 2.49 & 2.54 & 0.37 & 2.58 \\
\hline Commercial lodges & 1.37 & 1.79 & 1.42 & 1.53 & $4.56^{*}$ & 1.49 \\
\hline Hotels or motels & 1.19 & 1.56 & 1.32 & 1.37 & $5.29 *$ & 1.31 \\
\hline Security patrols & 3.70 & 3.43 & 3.76 & 3.55 & 1.61 & 3.64 \\
\hline Maps of the area showing trails, fishing areas ... & 4.44 & 4.22 & 4.56 & 4.49 & $2.12 * * *$ & 4.45 \\
\hline Facilities for other recreational opportunities & 4.07 & 4.02 & 4.18 & 4.06 & 0.43 & 4.07 \\
\hline FRA within a $1-3$ hour drive from home & 4.31 & 4.02 & 4.29 & 4.15 & 1.99 & 4.20 \\
\hline
\end{tabular}

${ }^{1}$ Rated on a scale of 1 to 5 , where $1=$ not at all desirable and $5=$ very desirable.

$* P \leq 0.01$.

** $P \leq 0.05$.

*** $P \leq 0.10$.

Significant differences occurred on some of the mean attitude scores among the specialization levels (Table 3 ). Beginners had the highest scores on sustainability and traditional timber management items whereas Veterans and Regulars scored the lowest. Beginners also scored lowest on preservation items and Veterans and Regulars scored highest. This suggests that as campers gain experience or become familiar with an area, they may also become more preservation oriented and less tolerant of traditional timber management.

Respondents' management preferences for FRA campgrounds indicate that facilities or services requiring further development of the campgrounds were rated as undesirable (mean $<3.0$ ) by the majority of respondents (Table 4 ). In particular, facilities requiring a high level of development and extraneous to the camping experience such as fast food outlets, lodges or hotels were rated the least desirable. In contrast, facilities and services requiring minimal development and compatible with a natural camping experience were rated as desirable (mean > 3.0). Items such as maps of recreational opportunities, facilities for hiking, fishing or biking, FRAs close to home, and security patrols of the campgrounds were rated as desirable. Showers at FRAs were rated about neutral (mean $=3.0$ ).

Differences were observed among the specialization clusters on some of the facility and service items (Table 4). Beginners were more tolerant of development at FRAs scoring higher than the other groups on showers, boat rentals, fast food outlet, lodges and hotels and scoring lower on maps of recreational opportunities. Veterans and Regulars tended to be the least tolerant of development at FRAs.

\section{Discussion}

This study demonstrates that campers in the Rocky Clearwater Forest do not represent one homogeneous group. Instead, four distinct subtypes were identified based on the amount of camping experience and their psychological attachment to the activity. Even though some groups were more tolerant of campground development than others, for the majority of FRA users increased facility development would not be acceptable.
Current users appear to be seeking a more natural camping experience than those offered by other publicly owned campgrounds such as provincial or national parks. Forest recreation areas apparently provide a unique camping opportunity for many Albertans. Recently, there has been an increased emphasis on privatization and development of campgrounds by the Alberta government. This study shows that current users are not in favour of increased development. If increased development occurs, campers seeking the experience offered at FRAs may move to more primitive sites as has been observed in previous studies (Clark et al. 1971). Indeed the findings suggest that because FRAs represent the least developed of formalized campgrounds in the province, development in the area would probably result in many campers moving to informal camping on public lands. This will exacerbate fire hazard and environmental impacts and defeat the original purpose of FRAs (McFarlane et al. 1996).

With regards to forest management, this study has shown that one stakeholder group using the Rocky-Clearwater, FRA campers, does not view current forest management practices as sustainable. Furthermore, this user group is not supportive of economic development associated with traditional timber management, and supports the preservation aspects of forest management. This suggests that the current movement toward an ecosystem management approach that considers nontimber values may be acceptable to this stakeholder group. Some groups, such as those most familiar with the area (Regulars) and those with the most camping experience (Veterans), may be affected more than others by changes in the forest. Educational efforts about the sustainability of current forest management practices in the area and on ecosystem based management in general and separation of recreational opportunities such as camping from industrial activity may help ease potential conflict between industrial and recreational stakeholders.

The forest attitudes scale represents the preliminary development of a standardized attitude measure that can be used to compare various stakeholder groups and to monitor attitude change through time. The scale was used to distinguish attitudes of subtypes of one stakeholder group. Development of 
a standardized forest attitude scale could provide a means of obtaining public input into forest management from the general public and several stakeholders in a cost effective and timely manner. However, further applications anu refinement of the instrument is required including tests on other stakeholders and factor analysis of scale items to check the stability and reliability of factors. Future research will include refinement of scale items and testing the instrument on other stakeholder groups such as other types of recreationists, forest managers, and the general public.

\section{Acknowledgements}

The research assistance of Maureen Dolphin, Ramona Maraj, and Bonnie Rush is greatly appreciated. We thank Kerry Edwards, Alberta Parks Services and Dave Coish, Alberta Land and Forest Service, for assistance with many aspects of the project. Funding for the study was provided by the CanadaAlberta Partnership Agreement in Forestry.

\section{References}

Bengston, D. N. 1994. Changing forest values and ecosystem management. Society and Natural Resources 7: 515-533.

Bryan, H. 1977. Leisure value systems and recreation specialization: The case of trout fishermen. Journal of Leisure Research 9: 174-187. Clark, R. N., J. C. Hendee and F. L. Campbell. 1971. Values, behavior, and conflict in modern camping culture. Journal of Leisure Research 3: 143-159.
Dunlap, R. E. and K. D. Van Liere. 1984. Commitment to the dominant social paradigm and concern for environmental quality. Social Science Quarterly 65: 1013-1028.

Jackson, E. L. 1986. Outdoor recreation participation and attitudes to the environment. Leisure Sciences 5: 1-23.

Jackson, E. L. 1987. Outdoor recreation participation and views on resource development and preservation. Leisure Sciences 9: 235-250. Kellert, S. R. 1985. Birdwatching in American society. Leisure Sciences 7: $343-360$.

Kimmins, J. P. 1995. Sustainable development in Canadian forestry in the face of changing paradigms. Forestry Chronicle 71: 33-40.

McFarlane, B. L., M. A. Dolphin and P. C. Boxall. 1996. Campers at forest recreation areas in west-central Alberta: A user profile. Nat. Resour. Can., Can. For. Serv., North. For. Cent., Edmonton, AB. For. Manage. Note 62.

McIntyre, N. and J. J. Pigram. 1992. Recreation specialization reexamined: The case of vehicle-based campers. Leisure Sciences 14: 3-15. SAS Institute, Inc. 1989. SAS/STAT users guide, version 6, vol. 1 (4th ed.). Cary, NC. 889 p.

Steel, B. S., P. List and B. Shindler. 1994. Conflicting values about federal forests: A comparison of national and Oregon publics. Society and Natural Resources 7: 137-153.

Van Liere, K. D. and F. P. Noe. 1981. Outdoor recreation and environmental attitudes: Further examination of the Dunlap-Heffernan thesis. Rural Sociology 36: 501-513.

Virden, R. J. and R. Schreyer. 1988. Recreation specialization as an indicator of environmental preference. Environment and Behavior 20: 721-739.

Williams, D. R. 1988. Recreational specialization: A complex issue for visitor management. Western Wildlands 14 (3): 21-26. 